\title{
$\langle-ト\rangle$
}

\section{活性污泥を用いる迅速 BOD の測定法}

\author{
宮 脇 美由貴* 古川正道* 鎌 田 栄二郎*
}

\section{Rapid BOD Measurement Using Activated Sludge}

\author{
Miyuki MIYAWAKI*, Masamichi FURUKAWA* and Eijiro KAMATA*
}

* Government Industrial Research Institute, Nagoya, 1-1 Hirate-cho, Kita-ku, Nagoya, Aichi 462 Japan

\begin{abstract}
A rapid and simple method for estimating BOD in waters was investigated by using a DO (Dissolved Oxygen) electrode and activated sludge acclimated to substrates. When the substrate was not added to the ML (Mixed Liquor) saturated with DO, a negative straight line for the DO decrease was obtained against the time signifying endogenous respiration of the activated sludge. On the other hand, when sodium sulfite or organic compounds was added as the substrate to the ML after a few minutes, the negative straight line with the similar slope to that obtained initially was obtained again, after a steep decrease in DO cocentration due to the biological oxidation of the substrate with the DO. The difference in DO concentration between two negative straight lines obtained before and after the addition of the substrate is directly proportional to the concentration of added substrate. This DO consumption is applied to determin the rapid BOD (BODr). The time required to measure the BODr is about 10 min. The present method was applied to the estimation of the BODr for some typical organic substrates such as ethanol, phenol, and glucose-glutamic acid with satisfactory results.
\end{abstract}

Key words : rapid BOD measurement, acclimated activated sludge, DO electrode, biological wastewater treatment

\section{1.はじめに}

活性污泥法による排水処理工程において，流入排水 中に含まれる生物学的に分解可能な有機物量を迅速に 把握し，適正な排水処理工程の維持管理を行うことが 求められている。そのためには, 排水中の BOD の迅速 な測定法の確立が必要とされる。Karube et al. ${ }^{1}$ ，鈴 木ら ${ }^{2)}$ は固定化微生物膜電極を用いる迅速 BOD 測定 装置を開発した。Siepmann ${ }^{3)}$ は外気を遮断したバイオ リアクター中で活性污泥懸濁液と検水を混合, 循環さ せ，反応前後の溶存酸素 $(\mathrm{DO})$ 濃度の差から迅速 $\mathrm{BOD}$ を求める測定装置を開発した。また, 石原ら ${ }^{4), 5}$ も活性 污泥を用いる迅速 BOD 測定装置を開発した。石原
ら ${ }^{4), 5)}$ の方法では，活性污泥の内生呼吸により，活性污 泥懸濁液中の DO が消費され，DO 濃度がゼロの状態 で検水を添加し，直ちに一定条件でばっ気して，反応 終了後急激に DO 濃度が増加を開始するまでの時間を 自動計測し, 予め作成された BOD 量と生物学的酸化 所要時間との関係から BOD 濃度を求めている。

本研究は，DO を飽和した活性污泥懸濁液中でばっ 気することなく，簡易，迅速に BOD（迅速 BOD： BODr）を測定する方法に関するものである。

本法においては，検水中の基質によく馴致された活 性污泥懸濁液を，均一に擤拌しながらばっ気して DO を飽和した後，DO 電極を用いて DO 濃度を連続的に 計測する。このとき DO 濃度は活性污泥の内生呼吸作

* 名吉屋工業技術試験所 $\overline{\mathrm{T}} 462$ 名古屋市北区平手町一丁目 1 番地 
用により直線的に減少するが，基質を添加するとその 生物学的酸化反応の進行の結果, DO 濃度は急激に減 少した後に安定化し，再び直線的な減少曲線を示す。 その際, 基質添加前と安定化後における $\mathrm{DO}$ 濃度の減 少曲線の勾配が等しくなり，ここで成立する平行線の 間の DO の濃度差が基質の添加量に比例する。本法は この現象を利用して短時間に BOD を求める方法であ る。

\section{2. 実験方法}

\section{1 活性污泥}

活性污泥は，都市下水処理の返送污泥をばっ気槽に 分取し，基質としてグルコース・グルタミン酸，フェ ノール・酶酸, メタノール・エタノールの等量混合物 に，それぞれ十分馴致されたものを実験に用いた。

\section{2 測定機器}

\subsubsection{BOD 反応槽}

ばっ気装置, 攪汼機, 温度および $\mathrm{pH}$ 自動調整装置付 きの角形の透明塩化ビニール製（容量 $6 l l ）$ を用いた。

\subsubsection{DO メーター}

エーブル製 M1032型を用いた。

\section{2 .3 記録計}

CHINO 製 EB22005型を用いた。

\section{3 ．迅速 BOD の測定方法}

BOD 反応槽中に，MLSS 濃度が $3,000 \sim 4,000 \mathrm{mg}$ $l^{-1}$ となるように活性污泥懸濁液を $5 l$ とり, 温度 $20 \pm$ $0.5^{\circ} \mathrm{C}, \mathrm{pH} 7 \pm 0.2$ 亿調整し，靦汼，ばっ気しながら DO を飽和する。MLSS 濃度は JIS K 0102の懸濁物質の 測定方法に基づき，重量分析法により測定する。活性 污泥懸濁液は DO を飽和した後, ばっ気を停止し，DO 濃度の減少曲線を連続的に計測する。 $3 \sim 4$ 分間経過 後，基質を含む検水を添加すると，生物学的酸化反応 の進行の結果, DO 濃度が急激に減少した後, 再び安定 化し，直線的な減少曲線を示す。検水添加前の DO 濃 度の減少曲線の勾配と検水添加後の DO 濃度の減少曲 線の勾配が等しいとき，両者の濃度の差から消費 DO 濃度を求め，その值を 5 倍（活性污泥懸濁液容量：5 l)したものが BODr の測定值となる。BODr の測定值 は， $\mathrm{gO}_{2} \cdot \mathrm{g}^{-1}$ (基質添加の場合）または $\mathrm{gO}_{2} \bullet l^{-1}$ （検水 添加の場合）として表示する。検水添加量は $100 \mathrm{~m} l$ ま でとする。測定時間は通常約10分である。ただし，反 応の遅い場合には，基質添加後 DO 濃度が再び直線的 な減少勾配を示すのに15２0分を要することがある。

\section{4. 実験結果および考察}

\section{1 基礎的条件の検討}

\section{1 .1 亜硫酸ナトリウムによる検討}

検水添加の前後における活性污泥懸濁液中の DO 濃 度の減少曲線の勾配の平行性と，その平行線の間の DO 濃度の差から求められる DO 消費量の定量性を確 認するために，ばっ気槽中の酸素移動速度測定に用い られている亜硫酸ナトリウム酸化法により検討した。 亜硫酸イオンの酸化触媒として, 硫酸コバルト $\left(\mathrm{CoSO}_{4} \cdot 7 \mathrm{H}_{2} \mathrm{O}\right)$ を $0.24 \mathrm{~g} \cdot l^{-1}$ (Co として $50 \mathrm{mg} \cdot l^{-1}$ ) 添加した後，10\%亜硫酸ナトリウム溶液を調製後直ち に添加する。なお亜硫酸ナトリウムの力価はヨウ素滴 定法により標定した。活性污泥懸濁液中に一定量の亜 硫酸ナトリウムを添加した場合の DO 濃度の減少曲線 をFig.1に示した。亜硫酸ナトリウムとして200mg （力価0.96）添加，すなわち DO 消費量として $24.38 \mathrm{mg}$ $\left(4.88 \mathrm{mg} \cdot l^{-1}\right)$ まで DO は定量的に消費された。この範 囲では，DO 濃度の減少曲線はブランク（検水添加前） の DO 濃度の減少曲線に平行な直線を引くことができ る。

本法は，外気と接触した状態で測定を行うため，液

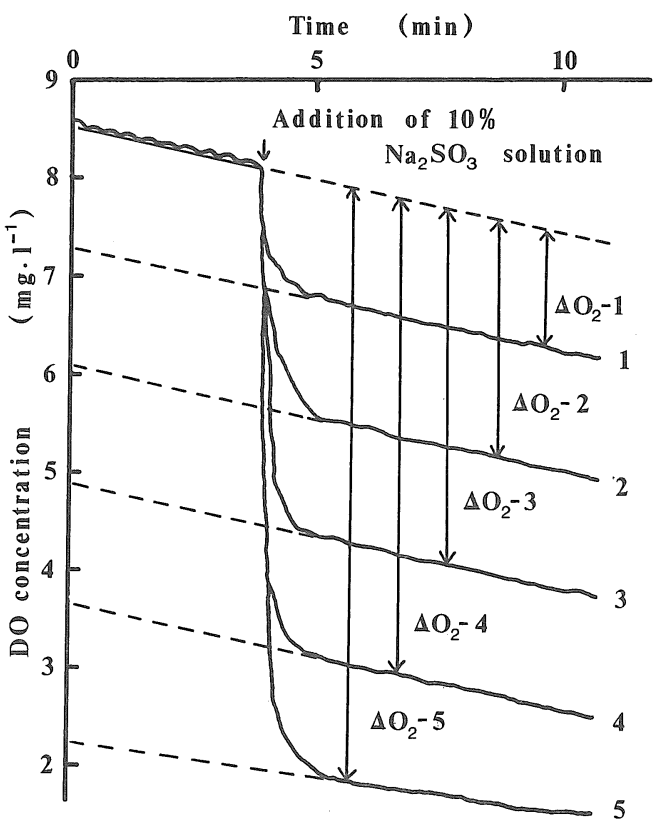

Fig. 1 Profile of DO decreased by addition of sulfite ion. Amounts of $\mathrm{Na}_{2} \mathrm{SO}_{3}$ added (mg) : $1=50$, $2=100,3=150,4=200,5=250$. The range represented by $\Delta \mathrm{O}_{2}-1, \Delta \mathrm{O}_{2}-2, \Delta \mathrm{O}_{2}-3, \Delta \mathrm{O}_{2}-4$ or $\Delta \mathrm{O}_{2}-5$ shows the $\mathrm{DO}$ consumption by sulfite ion. 
面から酸素の溶け込みの影響があり，酸化反応終了時 点の DO 濃度が低くなると，Fig.1の5のように反応 終了後の DO 減少曲線がブランクのそれと平行になら ない場合がある。このようなときには，消費 DO 量の 測定誤差が大きくなるが，反応終了後にわずかでも平 行な部分が得られる場合は，測定誤差はそれほど問題 にならない。液面からの酸素供給による測定誤差を低 減するためには，基質による DO 消費が検水添加時の DO 濃度の 40 ～50\%までになるような条件下で測定を 行うとよい結果が得られたので，污泥濃度，基質添加 量を検討し，このような条件下で測定を行うことが必 要である。

\section{1 .2 活性污泥濃度の影響}

基質に対する活性污泥による DO 消費量と活性污泥 濃度との関係を調べるため, 活性污泥懸濁液の MLSS 濃度 $2,000 \sim 6,000 \mathrm{mg} \cdot l^{-1}$ の範囲で，基質を一定量 $(10$ $\mathrm{mg})$ 添加した場合の DO 消費量 $\left(\Delta \mathrm{O}_{2}\right)$ を測定した (Fig.2)。その結果, MLSS 濃度3,000〜 $5,000 \mathrm{mg} \bullet l^{-1}$ の範囲でその DO 消費量 $\left(\Delta \mathrm{O}_{2}\right)$ は一定であった。しか し，その勾配は後述の Fig.3に示したように活性污泥 の濃度等により異なるから，その勾配を確認できる程 度に DO 濃度の減少を計測した後，検水を添加する。

\section{1 .3 検水添加量の影響}

検水添加量の測定值への影響を調べるために，基質 の一定量を添加すると同時に蒸留水を $50 \sim 200 \mathrm{~m} l$ 加 えた場合のDO 消費量の測定結果を Table 1 に示し た。検水添加容量が $100 \mathrm{~m} l$ でー3\%， $150 \mathrm{~m} l$ でー7\%の 誤差となるから，検水添加容量は $100 \mathrm{~m} l$ 以内が望まし w。

\section{2 迅速 BOD の測定}

グルコース・グルタミン酸馴養污泥とその基質によ る DO 消費量, すなわち BODr の測定例を Fig. 3 に示 した。ブシンクの DO 濃度減少曲線と平行関係を有す る基質添加後の DO 濃度減少曲線が得られる範囲内に

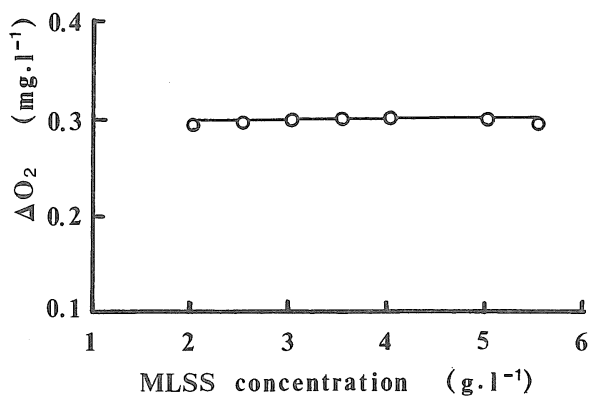

Fig. 2 Effect of the MLSS concentration on DO consumption $\left(\Delta \mathrm{O}_{2}\right)$. Amount of substrate (glucose -glutamic acid) added : $10 \mathrm{mg}$
おいては, 基質添加量と消費 DO 濃度は比例性がある。 それぞれの馴養基質によって馴養された活性污泥によ る各基質の濃度と DO 消費量の間の関係（検量線）を Fig. 4 に示した。各基質ともよい直線性を示している。

\section{3 各種基質の迅速 BOD の測定}

本研究で取り扱った三種の活性污泥による馴養基質 および非馴養基質の測定結果を Table 2 に示した。

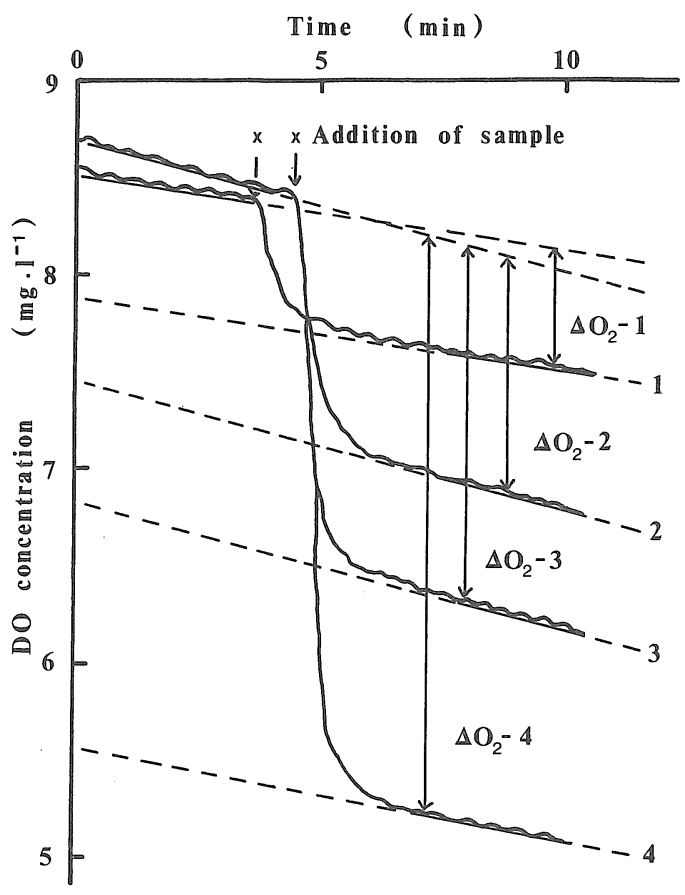

Fig. 3 Profile of DO decreased by addition of BOD -substrate (glucose-glutamic acid). Amounts of substrate added (mg): $1=10,2=20,3=30,4=$ 50. MLSS concentration $\left(\mathrm{mg} \cdot l^{-1}\right): 1=2,500$, $2-4=3,050$. The range represented by $\Delta \mathrm{O}_{2}-1$, $\Delta \mathrm{O}_{2}-2, \Delta \mathrm{O}_{2}-3$ or $\Delta \mathrm{O}_{2}-4$ shows the DO consumed by the substrates added.

Table 1 Effect of the sample volume on the DO concentration

\begin{tabular}{|ccc|}
\hline $\begin{array}{c}\text { Sample volume* } \\
(\mathrm{m} l)\end{array}$ & $\begin{array}{c}\text { MLSS } \\
\text { concentration } \\
\left(\mathrm{mg} \cdot l^{-1}\right)\end{array}$ & $\begin{array}{c}\text { DO concentration } \\
\left(\mathrm{mgO}_{2} \cdot l^{-1}\right)\end{array}$ \\
\hline 2 & 3,900 & 0.30 \\
50 & 3,860 & 0.30 \\
100 & 3,800 & 0.29 \\
150 & 3,780 & 0.28 \\
200 & 3,750 & 0.27 \\
\hline
\end{tabular}

* Mixture solution containing equal amounts of glucose and glutamic acid (10 mg glucose-glutamic acid) 
Table 2 Estimation of BODr for various substrates using acclimated or non-acclimated sludge

\begin{tabular}{|c|c|c|c|c|}
\hline \multirow{3}{*}{ Substrate } & \multirow{3}{*}{$\begin{array}{l}\mathrm{JIS}-\mathrm{BOD} \\
\left(\mathrm{gO}_{2} \cdot \mathrm{g}^{-1}\right)\end{array}$} & \multicolumn{3}{|c|}{$\underset{\left(\mathrm{gO}_{2} \cdot \mathrm{g}^{-1}\right)}{\mathrm{BODr}}$} \\
\hline & & \multicolumn{3}{|c|}{$\begin{array}{l}\text { Substrates for acclimation of } \\
\text { activated sludge }\end{array}$} \\
\hline & & $\begin{array}{l}\text { Glucose- } \\
\text { glutamic } \\
\text { acid }\end{array}$ & $\begin{array}{l}\text { Phenol- } \\
\text { acetic } \\
\text { acid }\end{array}$ & $\begin{array}{l}\text { Ethanol- } \\
\text { methanol }\end{array}$ \\
\hline $\begin{array}{l}\text { Glucose- } \\
\text { glutamic } \\
\text { acid* }^{*}\end{array}$ & 0.70 & 0.15 & 0.20 & 0.14 \\
\hline Glucose & 0.76 & 0.16 & 0.21 & 0.14 \\
\hline $\begin{array}{l}\text { Glutamic } \\
\text { acid }\end{array}$ & 0.68 & 0.12 & 0.26 & 0.13 \\
\hline Phenol & 2.10 & 0 & 0.98 & 0.82 \\
\hline $\begin{array}{l}\text { Acetic } \\
\text { acid }\end{array}$ & 0.86 & 0.27 & 0.59 & 0.50 \\
\hline Ethanol & 1.63 & 0.57 & 1.05 & 0.77 \\
\hline Methanol & 1.20 & 0 & 0.09 & 1.00 \\
\hline
\end{tabular}

* Mixture solution containing equal amounts of glucose and glutamic acid

Table 2 においては，比較のために JIS 法による BOD の測定值を示した。メタノールや酢酸は，それぞれの 基質によって馴養された活性污泥による測定では, JIS 法に近い測定值が得られた。しかし，その他の基質に ついてはJIS 法による BOD 值と比較して低い測定結 果が得られているが，これらの結果は基質濃度に対し て比例性がある（Fig.4）ことから，補正することに よって JIS 法に近似した測定值を求めることができ る。JIS 法による BOD 測定の所要時間が 5 日間である ことを考えると，活性污泥は短時間ではこの程度しか 生物学的酸化反応を進行させないと考えられる。また, メタノールなど炭素数の少ない基質の測定值がより大 きいことからも，その生物学的酸化反応の過程を反映 していると考えられる。

フェノール・酶酸馴養污泥は，グルコースやグルタ ミン酸に対してもより大きな測定值を示しているが, これは, McKinney et al.9lによって示されたように, フェノール馴化污泥は炭水化物，アミノ酸，脂肪酸な どを容易に物質代謝できる能力を有することによると 思われる。また，三種の污泥のいずれも酶酸に対して はより大きな測定值を示している。これは，基質の中 間代謝物として酶酸が生成されることが多いことによ ると思われる。しかし，グルコース・グルタミン酸馴 養污泥は,フェノールやメタノールに対しては BODr がゼロを示すように，これらの非馴養基質が生物学的 酸化反応を受けにくいことを示している。このように 本法により，活性污泥による基質の生物学的酸化反応

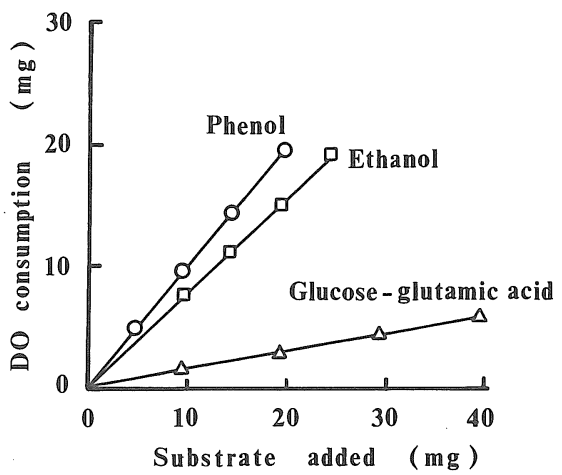

Fig.4 Typical calibration curves of various substrates

処理における DO 消費量，すなわち BODr を測定し， その基質の JIS 法による BOD 值と比較することによ り，活性污泥の基質に対する生物処理能力を推定する ことができる。

\section{5.まとぬ}

DO を飽和した活性污泥懸濁液において，検水添加 前後の DO 濃度減少曲線の勾配が同じになった時点で の DO 濃度の差が，添加した基質濃度に比例すること を利用して，簡易，迅速に BODr を求める方法を開発 した。

本法は，外気と接触した状態（DO が供給される状 態）で測定を行うため, 基質添加後の DO の減少曲線 が平行にならない場合もあるが，わずかでも平行な部 分が得られれば測定は可能である。液面からの酸素供 給による測定誤差を低減するためには，基質による DO 消費が検水添加時の DO 濃度の 40 ～50\%までにな るような条件下で最もよい結果が得られたので，污泥 濃度，基質添加量を検討し，このような条件下で測定 を行うことが必要である。

本法では, 活性污泥懸濁液の MLSS 濃度が $3,000 \sim 5,000 \mathrm{mg} \cdot l^{-1}$ の範囲で，その濃度の影響を受け なかった。また，検水添加量は測定誤差への影響を考 慮して $100 \mathrm{~m} l$ までとする。測定時間は通常約 10 分で あった。

本法は, DO で飽和した状態で,ばっ気することなく 活性污泥懸濁液による基質の生物学的酸化反応過程を 測定しているので，ばっ気による大量の酸素供給を行 う場合では測定不可能な，基質の生物学的酸化反応が 遅い場合でも十分適用可能であり，活性污泥の基質に 対する生物処理の可能性についての目安を与えるもの である。今回は蒸留水と標準試薬を用いて調整した基 質の測定のみしか行わなかったが，活性污泥処理工程 
水等の実際試料においても，還元性の無機物質に対す る考慮を加えれば，この方法は十分適用可能であると 考える。また，本法は活性污泥濃度を厳密に測定する 必要がなく，計測された DO 濃度のデー夕を，コン ピューターにより演算処理することができるから，容 易に装置化することが可能である。

（原稿受付 1991年 3 月22日）

(原稿受理 1991 年 8 月 6 日)

\section{引用文 献}

1) Karube, I., Mitsuda, S., Matsunaga, T., and Suzuki, S. (1977) A rapid method for estimation of BOD by using immobilized microbial cells, Ferment. Technol., 55, 243-248.
2 ) 鈴木周一, 軽部征夫, 安田武夫, 引間基彦, 大矢芳彦, 引田 健一郎, 中井康二 (1982) 微生物センサを用いた BOD 連続測定 システム，日新電機技報，27，62-66。

3 ) Siepmann, F.W. (1985) Die kontinuierliche kurzzeit-BSB -Messung (BSB-3), Gewasser-schutz, Wasser, Abwasser, 77, 233-256.

4 ) 石原豊, 田中一彦 (1984) 活性污泥を用いる BOD 迅速測定法, 水処理技術，25，487-493.

5 ) 石原豊, 田中一彦, 中嶋邦雄, 中島良三 (1985) 活性污泥を 用いる短時間 BOD 測定装置の試作, 水処理技術, 26, 29-33。

6 ) Suschika, J. and Ferreira, E. (1986) Activated sludge respirometric measurements, Wat. Res., 20, 137-144.

7 ) McKinney, R.E., Tomlinson, H.D. and Wilcox, R.L. (1956) Metabolism of aromatic compounds by activated sludge, $S$. \& I. W., 26, 547-557. 
を平成元年の 5 月と11月に調査した。調査対象井戸は36井である。その結果，検出率は，トリクロロエチレン $42 \%$ ，テトラクロロエチレン25３1\%，1,1,1-トリクロロエタン22３3\%で，四塩化炭素はどの井戸からも検 出されなかった。水道水の暫定水質基準を超えたものは，トリクロロエチレン 4 地点，テトラクロロエチレン 2 地点であった。

また，菅地区における1,1,1-トリクロロエタンの污染源追跡調査の結果，污染物質の検出が地下水位に関係 していることから污染物質の埋設が考えられたが確定には至っていない。

\section{活性污泥を用いる迅速 BOD の測定法}

宮脇 美由貴* 古川 正道* 鎌田 栄二郎*

* 名古屋工業技術試験所

〈水質污濁研究 Vol. 14 No.12（1991） pp.883〜887〉

DO (溶存酸素) で飽和した活性污泥懸濁液の液面が外気と接触した状態で，ばっ気することなく懸濁液中の DO 濃度の減少を連続的に計測した場合，DO 濃度は直線的に減少する。検水（基質または有機污濁物を含む） を添加すると急激に減少した後, 安定し再び直線的な減少勾配を示す。DO 濃度の減少勾配が検水添加前と同じ になった時点で成立する平行線の間の DO 濃度の差が添加した基質濃度に比例することから，簡易，迅速に $\mathrm{BOD}$ (迅速 BOD) を求める方法である。検水採取量は $100 \mathrm{~m} l$ までとする。本法の測定時間は約 10 分である。本 法では, 活性污泥濃度は MLSS として $3,000 〜 5,000 \mathrm{mg} ・ l^{-1}$ の範囲で, 検水の迅速 BOD 測定に影響を与えない。 